\section{El discernimiento de Jesús como pobre de Yahveh e hijo de la tierra*}

\author{
RAFAEL LUCIANI ${ }^{* *}$
}

RECIBIDO: 15-12-15. APROBADO: 17-08-16

Resumen: El artículo aborda el proceso de discernimiento de Jesús en medio de las diversas tradiciones de su época y a partir de su espiritualidad como pobre de Yahveh e hijo de la tierra. Se irá mostrando cómo la imagen que él tenía de Dios brota de una teología creacional que permite aproximarse a las cuestiones que impactaron profundamente a sus seguidores: sus opciones fundamentales, su distanciamiento de las expectativas religiosas y políticas establecidas, su modo particular de usar y orar desde las escrituras, la imagen de Dios que siguió y todo lo que escandalizó de su apuesta en favor de las víctimas y los pobres.

Palabras clave: Yahveh, filiación, pobres, cristología, creación.
The Discernmet of Jesus as Poor of Yahveh and as Son of the Land

Авstract: This article refers to Jesus' process of discernement in the midst of the diverse traditions of his time, process that was based on his spirituality as poor of Yahveh and as son of the land. The article will show how Jesus' image of God arose from a creational theology that allows us to approach the issues that made an impact on Jesus' followers: his basic options, his estrangement from the established religious and political expectations, his particular way of using the Scripture and of praying from it, the image of God that he followed, and the scandal produced by his choice in favor of the victms and the poor.

Key words: Yahweh, Filiation, Poor, Christology, Creation.

PARA CITAR ESTE ARTÍ́CULO:

Luciani, Rafael. "El discernimiento de Jesús como pobre de Yahveh e hijo de la tierra". Theologica Xaveriana 182 (2016): 421-447. http://dx.doi.org/10.11144/javeriana.tx66-182.djpyht

* Ensayo de reflexión desarrollado en diálogo con las investigaciones cristológicas más recientes que se están publicando en distintos idiomas y escuelas de reflexión teológica.

** Doctorado en Teología y Licenciatura en Teología Dogmática, Pontificia Università Gregoriana, Roma; actividades postdoctorales en la Julius-Maximilians Universität, Würzburg, Alemania. Profesor titular de la Universidad Católica Andrés Bello, UCAB; professore stabile de la Università Pontificia Salesiana, Roma; profesor en Boston College, EE.UU. ORCID.orG/0000-0002-5067-2054. Correo electrónico: lucianir@bc.edu 


\section{Introducción}

Uno de los problemas a enfrentar en cualquier estudio sobre la vida y el proyecto de Jesús es la tentación de descontextualizarlo de su mundo vital, o el trabajo en pos de hacerlo cristiano, por así decir. Como afirman estudios recientes, muchos "teólogos del Nuevo Testamento comienzan, generalmente, su interpretación desde la premisa que los escritores y los lectores de esos textos eran cristianos, y ya no se sentían a sí mismos como judíos" ${ }^{1}$. La consecuencia es evidente. Se buscará adaptar el Antiguo Testamento al Nuevo llevando a un cambio de significados evidentes en la comprensión de la persona de Jesús y su proceso de discernimiento personal y social.

Este ensayo, siguiendo lo que el XXI Concilio Ecuménico Vaticano II propició, pretende ofrecer algunos elementos para comprender la relevancia de la vida y la praxis de Jesús de Nazaret, de su personalidad histórica. En otras palabras, la espiritualidad que fue moldeando su modo de hacerse humano ${ }^{2}$ en tanto lugar fundamental para comprenderlo como sujeto que buscó siempre discernir y reconocer los pasos del rostro del Dios vivo y verdadero por medio de su vida ${ }^{3}$.

La humanidad de Jesús porta un carácter paradigmático, tanto en lo referido a su "pretensión histórica" como en "la singularidad de su praxis" (DV2) y la asunción de su "destino" (GS 22; 38). Esto implicó en Jesús un proceso de discernimiento de su identidad y misión de cara a las tradiciones religiosas existentes y a la realidad sociopolítica que se vivía en el siglo I.

De ahí surgen la novedad de su apuesta por el Dios del Reino asumida desde la espiritualidad de los pobres de Yahveh e hijos de la tierra, y el tratamiento que da a su Padre como el Dios de la vida, de la justicia, de la paz, de la misericordia y de los pobres; el Dios que da vida al que no la tiene, que trae justicia a las víctimas, que consuela a los pobres, que perdona a los pecadores y fraterniza con todos.

\section{Releer la vida de Jesús a la luz del Antiguo Testamento \\ Hermenéutica y unidad de ambos testamentos}

Si no se comprende la unidad fundamental entre los dos testamentos, se hará difícil o extraño hablar del propio proceso de discernimiento y conversión de Jesús a Dios,

\footnotetext{
${ }^{1}$ Por tanto, asevera Rendtorff en el mismo texto que "los teólogos bíblicos deberían estudiar el Nuevo Testamento, ante todo, como un escrito redactado por judíos, que se entendieron a sí mismos en continuidad con la Biblia (en hebreo o arameo, e incluso en griego)" (Rendtorff, "Old Testament Theology, Tanakh Theology, or Biblical Theology? Reflections in an Ecumenical Context”, 450).

${ }^{2}$ Uríbarri, La singular humanidad de Jesucristo, 398ss.

${ }^{3}$ Concilio Vaticano II, "Constitución dogmática Dei Verbum sobre la divina revelación” 2; ídem, "Constitución pastoral Gaudium et spes sobre la Iglesia en el mundo actual” 38.
} 
a ese Dios de Abraham, Isaac y Jacob que se le reveló a Moisés en el monte Sinaí y que estableció una alianza ${ }^{4}$ eterna con su pueblo como único Señor de la historia. Ese acontecimiento fundacional de la revelación de Dios como Yahveh ${ }^{5}$, el mismo que acompañó a Israel al escapar de Egipto, será decisivo para Jesús como judío de su época.

Desde esta experiencia, él se dispondrá a tratar a Dios de forma personal, a discernir el modo como se hace presente en su vida diaria hasta experimentarlo como Padre y Dios del Reino. Jesús va descubriendo cómo la alianza estaba aconteciendo, nuevamente, de modo completamente nuevo en el Reinado de Dios ${ }^{6}$, porque Yahveh no se había olvidado de su pueblo ni le había volteado su rostro, a pesar de los corazones duros e incrédulos que no apostaban por un mundo mejor.

No es posible pensar que existían visiones contrapuestas -la de Jesús y la del resto del judaísmo-, pues a Jesús se le confiesa como el Cristo y se le sigue inicialmente en el marco del judaísmo ${ }^{7}$. Negar esto significa adoptar una visión fundamentalista, literal, que solo proporcionará mayor desconocimiento sobre las razones por las cuales Jesús no asumió muchas de las lecturas en torno de Dios, el hombre y el mundo, que existían en la amplia variedad religiosa del judaísmo del primer siglo. Más aún, se corre el peligro de perder la vision de conjunto de ambos testamentos, instrumentalizando los textos del Antiguo respecto del Nuevo, sin comprender que en este está incluido el Antiguo ${ }^{8}$.

Por ejemplo, cuando el Nuevo Testamento cita al Antiguo', sus expresiones no se pueden comprender como palabras o frases aisladas, carentes del contexto previo que les da su sentido y de otro presente en el que se actualizan ${ }^{10}$. Ellas no cumplen

${ }^{4}$ Precisamente es esta centralidad del acontecimiento de la alianza que Jesús asume y expande, lo que permite hablar de una profunda unidad entre ambos testamentos. Como señala Lohfink: “...en la más reciente discusión acerca de lo central del Antiguo Testamento, la respuesta que más ha sobresalido, y que a mí por lo menos me convence más, es la que mejor se deja resumir en la llamada fórmula de la alianza" (Lohfink y Pesch, Weltgestaltung und Gewaltlosigkeit. Ethische Aspekte des Alten und Neuen Testaments in ihrer Einheit und ihrem Gegensatz. Düsseldorf, 16).

${ }^{5}$ Gese, Vom Sinai zum Zion, 21.

${ }^{6}$ En el texto que expresa la alianza - "Yo seré tu Dios, y ustedes serán mi pueblo" - se nos revela "lo que en el Nuevo Testamento luego será llamado el Señorío de Dios" (Lohfink y Pesch, Weltgestaltung und Gewaltlosigkeit. Ethische Aspekte des Alten und Neuen Testaments in ihrer Einheit und ihrem Gegensatz, 17).

${ }^{7}$ Se trata, ante todo, del lugar donde el cristianismo se desarrolla, lo que es vital para el proceso de su autocomprensión, porque este hecho "no es por casualidad así, sino ciertamente y ante todo, porque así corresponde a la praxis de la vida cristiana” (Lohfink, Das Jüdische am Christentum. Die verlorene Dimension, 69-70).

${ }^{8}$ Gese, Vom Sinai zum Zion, 30.

${ }^{9}$ Fitzmyer, The Semitic Background of the New Testament: Essays, Vol. I, Cap. I.

${ }^{10}$ La maravillosa introducción de Westermann, Das Alte Testament und Jesus Christus. 
la función de ser "pruebas bíblicas" de un pasado que, simplemente, se "realiza" de forma predeterminada en Jesús ${ }^{11}$. Tendrán que asimilarse como actualizaciones ${ }^{12}$ fruto de relecturas que harán sus seguidores en el marco de la confesión de fe de que él es el Mesías enviado por Dios para traer la Buena Noticia de liberación a los pobres.

Más aun, esta confesión surge de la experiencia de un testigo, de alguien que ha sido impactado por sus palabras, gestos, acciones y el modo como asumió el destino final; de alguien que cree en el proyecto del Reino, que pertenece al Padre, al Dios de Jesús.

En este sentido, el Nuevo Testamento es el Antiguo Testamento aconteciendo de manera completamente nueva, definitiva y plena en la persona del Nazareno, a quien luego sus seguidores confesarán como el Mesías de su fe, y en quien las escrituras se hicieron carne de su carne y promesa acontecida ${ }^{13}$. Él, como Mesías, inauguró un nuevo estilo de vida en el que la paz y la justicia eran posibles, devolvió la esperanza anhelada a los pobres que deseaban un futuro mejor, exhortó a compartir el pan y la vida en un único banquete donde todos pudieran sentarse sin excluirse o despreciarse.

En fin, él llegó a establecer algo que pocos creían posible, porque mientras muchos trataban de forzar la presencia del Reino por la vía violenta (Mt 11,12), Dios, sin embargo, acontecía en las palabras y acciones no violentas y compasivas de este hombre. Él no liberaba haciendo uso de la fuerza y el sometimiento, sino mediante la cercanía de una humanidad fraterna (Mc 9,19ss.) ${ }^{14}$.

\footnotetext{
${ }^{11}$ Por ello, no se puede aceptar que se lea como "una simple 'realización' de las antiguas profecías, como si se tratara de una programación predeterminada que se lleva a cabo de acuerdo con un plan establecido de antemano" (Vasco, Le Psauties de Jésus. Les citations des Psaumes dans le Nouveau Testament, I, 47).

${ }^{12}$ Se trata de un proceso de "asunción, o actualización de lo envejecido. Sin embargo, eso no hay que entenderlo de tal modo que pudieran asignársele muchas otras connotaciones de manera indiscriminada. Es el reflejo literario de un acontecimiento: el de la aparición de Jesús de Nazaret. Él fue considerado como la plena realización de lo que había sido entendido como cumplimiento de la voluntad social en Israel, como la consumación de todas las promesas" (Lohfink, Das Jüdische am Christentum, 225-226).

${ }^{13}$ Por ejemplo, metodológicamente Vermes comprende a los Sinópticos no como un corpus independiente y aislado, sino dentro de un proceso evolutivo que responde a una etapa que forma parte de un largo proceso de desarrollo de la Biblia y otros escritos del judaísmo (Vermes, La religión de Jesús, el judio, 24-25).

${ }^{14}$ En este sentido, la relevancia del Jesús histórico consiste en redescubrir la revelación misma de Dios en Jesús, ver detrás de cada palabra y hecho una pretensión particular y única que plantea cuestiones fundamentales a los contenidos de la fe. En fin, "esta pretensión de majestad es el comienzo del cristianismo" y por ello, el estudio del Jesús histórico es “la tarea central de la investigación acerca del Nuevo Testamento" (Jeremias, Abba. El mensaje central del Nuevo Testamento, 212). Jeremias se distancia, así, de Bultmann, y de todos los que pretenden hacer una cristología kerygmática, pero sin base en el seguimiento histórico. Esto sería -en palabras de Bultmann- que "la significación mesiánica que Jesús tiene para la comunidad primitiva no se basa tampoco en que él sea entendido como personalidad que aparece detrás de su doctrina con una fuerza impresionante, ni en el hecho de que la piedad, la obediencia que él exige, estén vivientes
} 
¿Cómo se fue gestando este proceso de discernimiento y praxis tan particular en Jesús si había otras visiones y creencias en torno del actuar de Dios en el siglo I? Podemos decir que bebiendo de las escrituras o-como señaló a su familia y seguidoresescuchando la palabra del Padre y poniéndola en práctica (Lc 8,21).

\section{A la luz de las escrituras}

En el fondo, este tipo de dificultades tienen su origen en el enfoque hermenéutico que se use. Por ejemplo, numerosas aproximaciones contemporáneas acerca de la vida del Jesús histórico han pretendido usar los textos del Nuevo Testamento de forma aislada, con la sola preocupación de estratificarlos hasta lograr probar lo que pudo haber dicho o hecho Jesús mismo, y lo que posteriomente fue construido por las comunidades pospascuales $^{15}$. O se han quedado en la sola pretensión de comprender a Jesús en el marco histórico del judaísmo del siglo ${ }^{16}$, pero sin ver la trascendencia que brotó del espíritu con el que vivió a la luz de las escrituras, lo cual provocó una novedad radical respecto del mismo judaísmo.

Una investigación puramente descriptiva, aunque llegue a conclusiones ciertas, no logrará transmitir el impacto que produce la humanidad de Jesús en el hoy de nuestra historia iluminando los problemas que afrontamos globalmente. Puede caer en un academicismo instrancendente que relativice el espíritu con el que Jesús actuó, aquello que lo movió e inspiró a asumir el proyecto del Reino, la significación que tiene el hecho de vivir así, y lo que atrae de su vida, de su mensaje, a todo sujeto, más allá de las religiones o creencias. En fin, es importante considerar la experiencia religiosa de su propio proceso de discernimiento y conversión al Dios vivo y verdadero,

en él de tal manera que induzca fascinando a su seguimiento a aquellos que están abiertos a su acción” (Bultmann, Teología del Nuevo Testamento, 77).

${ }^{15}$ Para un seguimiento más completo de este tema sugiero el siguiente escrito, donde se explican, en detalle, las distintas escuelas y las posiciones de los investigadores, tanto clásicos como contemporáneos: Luciani, "El Jesús histórico como norma hermenéutica para la teología y criterio para ser testigos en el seguimiento", 17-116).

${ }^{16} \mathrm{~A}$ lo largo del siglo xx comenzó a desarrollarse el interés por la figura histórica de Jesús con la pretensión de recuperar la imagen judía. Entre las obras clásicas que destacan podemos señalar las siguientes: Klausner, Jesús de Nazaret. Su vida, su época, sus enseñanzas (Jesus of Nazaret. His life, times and teachings, 1929); Montefiore, Some elements in the religious teaching of Jesus (1910); idem, "The Significance of Jesus for His Own Age”. Hibbert Journal (1911-1912), "The Originality of Jesus". Hibbert Journal (1929), "What a Jew Thinks about Jesus”. Hibbert Journal (1934-1935); Ben-Chorim, Bruder Jesus. Der Nazarener in jüdischer Sicht (1976); Winter, El proceso a Jesús (1983); Vermes, Jesus the Jew. A Historian's Reading of the Gospels (1973); idem, Jesus and the World of Judaism (1983); idem, The Religion of Jesus the Jew (1993); Flusser, Jesus in Selbstzeunissen (1968); idem, Das Christentum, eine jüdische Religion (1990). 
y el modo compasivo y fraterno como se entregó a los hijos de este mundo para hacerlos hermanos suyos.

Muchas son las preguntas que nos podemos hacer, por ejemplo: ¿Cómo fue el proceso de conversión de Jesús? ¿De qué modo se perfiló en él una humanidad capaz de comunicar la calidad de vida divina que provocaría la atracción de muchos? ¿Por qué no siguió las expectativas establecidas, en lo religioso y político, en cuanto al modo de entender la fidelidad a Dios y la entrega a los demás? ¿Qué impactó e incluso escandalizó del modo como interpretaba las escrituras?

Estas cuestiones no se responden desde conclusiones dogmáticas. Ellas nos remiten a la necesidad de discernir la humanidad de Jesús, en cuanto paradigma, a partir del proceso de quien quiso y decidió ser fiel al Dios vivo y verdadero, actualizando en su contexto la experiencia del Dios de Abraham, Isaac y Jacob ${ }^{17}$. Esto significa que Jesús fue tejiendo su propia manera de interpretar y vivir según las escrituras.

Todavía más, si aceptamos que "en él reside toda la plenitud de la divinidad corporalmente" (Col 2,9), esta corporalidad humana no solo se caracteriza sociológicamente por ser la de un judío galileo del primer siglo, sino que ante todo se vive y sitúa a sí misma en una espiritualidad específica: la de los pobres de Yahveh. Desde esta espiritualidad que se nos da a conocer en el mundo bíblico, Jesús fue discerniendo los rasgos de su humanidad que se correspondían fielmente con el proyecto del Reino, seleccionando las tradiciones proféticas y sapienciales que expresaban mejor la imagen que brotó de su experiencia del Dios del Reino como Padre, en cuya maternidad bondadosa siempre lo sintió actuando con misericordia.

Como todo pobre de Yahveh, él oraba con los salmos y otras oraciones que aprendió tanto con su familia, como en las visitas a la sinagoga ${ }^{18}$ de Nazaret, donde creció. Tales textos - que hacen parte de lo que hoy llamamos el Antiguo Testamentoeran la fuente de vida en la que Jesús había crecido. En ellos encontró cuestiones debatidas en la época, muchas controversiales, que luego discutió con grupos como los fariseos, los saduceos y los escribas.

Por eso, cuando hablamos de la relación existente entre Jesús y el Antiguo Testamento, no entendemos una acomodación del Antiguo Testamento para legitimar el proyecto de Jesús. Se trata de correlacionar ${ }^{19}$ el modo como él vivió -según las

\footnotetext{
${ }^{17}$ Esta forma filial de ser humano es constitutiva a Jesús, pero él la irá asumiendo en su proceso de toma de conciencia de su propio ser y de la responsabilidad que ello conlleva, como será luego expresado en la narrativa teológica sobre su bautismo (Dunn, Jesus and the Spirit, 39).

${ }^{18}$ Kimball, "Jesus' Exposition of the Old Testament in Luke’s Gospel”, 101.

19 "Jesús mismo interpreta a las escrituras, así como estas lo interpretan a él. Él les dona su sentido último y definitivo" (Vasco, Le Psauties de Jésus, I, 53).
} 
escrituras y como oyente de la palabra del Padre- con el modo como luego sus seguidores, impactados por ese estilo de vida, debían transmitirlo en un contexto hermenéutico judío.

De hecho, dichos seguidores tuvieron que regresar a Galilea (Mt 28,10) y pensar a Dios desde lo que ahí aconteció en Jesús ${ }^{20}$. Así lo comunicaron pospascualmente al dejarse sorprender por esos recuerdos que no les dejaban tranquilos, porque los afectaban profundamente en su propia $\mathrm{fe}^{21}$.

Ciertamente no se puede, en muchos casos, saber cuáles fueron los textos exactos que usó Jesús, o llegar a las mismas palabras que pudo haber pronunciado; pero sí es posible que lleguemos a identificar el impacto que causó su estilo de vida y conocer cuáles tradiciones de las escrituras resonaban en él más que otras ${ }^{22}$ : es decir, la imagen de Dios que él comunicaba de forma específica y que contrastaba con otras tradiciones y teologías existentes en el siglo I.

Esta novedad fue precisamente lo que tanto impactó a los que lo acompañaban eventualmente, $\mathrm{o}$ a quienes rumoreaban acerca de sus acciones, e incluso a sus primeros seguidores. Si en él las promesas mesiánicas se hacían presentes, si los bienes de la tierra eran compartidos, si la esperanza era devuelta a los desdichados y enfermos, si los lazos perdidos de la fraternidad comenzaban a concretarse en una nueva manera de vivir como familia no biológica, entonces, ¿cómo no creer que en él ya ese Reinado de Dios anunciado, esperado, se estaba patentizando? (Mc 1,15). Además, ¿cómo aceptar que esto significaba una opción personal por asumir ciertas tradiciones y poner de lado tantas otras?

El mismo Lucas manifiesta esta indisoluble unidad y correspondencia entre el Nuevo Testamento y el Antiguo ${ }^{23}$, al reconocer haber releído las distintas tradiciones recibidas, para actualizarlas a la luz de esta nueva vida (Lc 1,1-4). El nuevo paradigma hermenéutico para leer las escrituras era ahora el modo como el mismo Jesús las había releído, pues había surgido algo nuevo que no cabía en moldes predestinados ni podía ser reducido a una alternativa más ${ }^{24}$.

\footnotetext{
${ }^{20}$ Por ello, cada evangelista releerá las acciones y las palabras de Jesús, y las actualizará a la luz de las escrituras, dotándoles de un sentido más pleno (ibíd., I, 47).

${ }^{21}$ Solo tenemos acceso a lo que sus primeros seguidores recuerdan de Jesús. En tal sentido, él solo podrá ser percibido, y comprendido realmente mediante el impacto que él produjo en sus vidas; y eso es lo que se llama fe (Dunn, Christianity in the Making: Jesus Remembered, I, 132).

${ }^{22}$ Lohfink, Das Jüdische am Christentum, 115-117.

${ }^{23}$ Podemos decir que "el Nuevo Testamento es en sí mismo incomprensible, y el Antiguo Testamento se puede prestar a cierta ambigüedad”. Hay que leerlos siempre en conjunto y a la luz de la praxis de Jesús (Gese, Vom Sinai zum Zion, 30).

${ }^{24}$ Ciertamente, la pretensión de Jesús no fue fundar una nueva religión, como lo recordó Reimarus en su clásico Von dem Zwecke Jesu und seiner Jünger, $\$ 3$. Sin embargo, esto no quita que tal fuera la novedad
} 
En este sentido, el Sitz im Leben en el que Jesús discierne no se puede descontextualizar de su realidad de ser un judío ${ }^{25}$ galileo $^{26}$ quien además vive como pobre de Yahveh e hijo de la tierra, en medio de una cultura sometida por el poder romano, bajo los rápidos cambios e inequidades socioeconómicas que surgían como consecuencia de las políticas clientelares de Antipas. De ahí que nos podemos preguntar: ¿Cuáles son esas tradiciones que van moldeando a Jesús y que causan impacto en sus seguidores? ¿Qué tipo de espiritualidad vive Jesús que le permite descubrir el rostro del Dios vivo?

\section{La espiritualidad de los pobres de Yahveh e hijos de la tierra}

Jesús no se presenta desde la descendencia mesiánica davídica, ni sintonizando con la teología deuteronomista del Dios fuerte y poderoso; tampoco con las aspiraciones restauracionistas de la teología de Sión. Él no ora desde una espiritualidad nacionalista y triunfalista, como muchos grupos que existían durante el periodo del segundo Templo. Antes bien, paradójicamente, asume un modo personal de tratar a Dios como creador y padre. Y lo hace desde su humanidad frágil, dispuesta como Hijo del Hombre que se entrega solidariamente al pobre.

Su forma peculiar de tratar a Dios revela lo propio de su espiritualidad, de la cual brotará el modo como se entiende a sí mismo y a los demás. Desde el inicio de su vida pública, Jesús se identifica con los pobres de Yahveh y los hijos de la tierra (Lc 4,18). Es a ellos y como uno de ellos a quienes ofrece una Buena Noticia de parte de $\operatorname{Dios}^{27}$; pero, ¿̨cuándo surge y qué caracteriza a esta espiritualidad tan peculiar?

de su vida y, luego, la ruptura radical de sus discípulos con el judaísmo, que dio paso al surgimiento del cristianismo. Como recuerda Klausner: por una parte, Jesús nació, vivió y murió en Israel siendo judío; por otra, los discípulos se alejaron de Israel y fueron rechazados por los sectores judíos más poderosos, provocando el nacimiento del cristianismo. Véase a Klausner, Jesús de Nazaret. Su vida, su época, sus enseñanzas, 9.

${ }^{25}$ Recordemos la afirmación que Julius Wellhausen haría en 1905, influenciando las futuras etapas en la investigación sobre el Jesús histórico, al recordar que Jesús no era un cristiano, sino un judío que enseñaba la radicalidad de la voluntad de Dios, pero sin basarse en la autoridad de la Ley ni en los medios tradicionales usados por los maestros y letrados de la época: "Jesús no fue cristiano, sino judío. Él no predicó ninguna fe nueva, sino que enseñó a cumplir la voluntad de Dios. Dicha voluntad se encontraba tanto para él, como para los judíos, en la Ley y en las escrituras. Sin embargo, él señaló otro camino para cumplirla, distinto al de los judíos piadosos y a lo que los líderes religiosos oficiales consideraban como el correcto y que cumplían escrupulosamente" (Wellhausen, Einleitung in die drei ersten Evangelien, 113).

${ }^{26}$ Es interesante la descripción que nos hace Reed, según la cual "los galileos veían a Jerusalén como una especie de axis mundi, y la peregrinación era común. La crítica era posible, como la habían hecho los profetas antiguos, pero esta se hacía de cara a la explotación social y la percepción de las fallas en el sistema, y no por lo que representaba la centralidad de Jerusalén" (Reed, Archaeology and the Galilean Jesus, 24). También se puede consultar el clásico de Büchler, Der galiläische 'Am-ha 'Arets des zweiten Jahrhunderts. ${ }^{27}$ Lohfink, Option for the Poor, 74. 


\section{Rasgos sociales y religiosos}

Para comprender mejor esta espiritualidad debemos recordar su origen o las primeras referencias -hacia el siglo VII a. C., durante la época del exilio-, cuando parte del reino de Judá fue deportado a Babilonia y no había más Templo ni culto, sino la escucha de la palabra. En el libro del profeta Sofonías destacan dos elementos importantes de lo que se vivió en este periodo: primero, la llamada que hace el inspirado a retomar el camino de la fidelidad a Yahvé; y segundo, la promesa que hace Yahveh a los pobres, los anawin, de recibir las bienaventuranzas divinas.

Sofonías emite un juicio severo ante el estado de cosas que violaba los derechos humanos del pueblo, y a la vez contra todo lo que promovía los ritos idolátricos cananeos, las supersticiones astrales asirias, todo lo que auspiciaba la corrupción de los comerciantes de Jerusalén. Ante esta situación, advierte que acontecerá el día de Yahveh (So 1,7), en el que solo resultarán favorecidos los humildes, los pobres, quienes hayan sido fieles a Yahveh.

A los pequeños y pobres que son hijos de la tierra-am ha-arez-se les reconoce la herencia de las promesas futuras de Israel (So 2,3 $)^{28}$ porque han confiado en Dios y se han dispuesto humildemente a su palabra. Ellos "heredarán la tierra" (Sal 37,11), y no los políticos corruptos, los profetas falsos o los sacerdotes perversos que no "escucharon", que no "confiaron" ni se "acercaron" a su Dios (So 3,2-4). En Jesús resonarán palabras similares, al recordar que los pobres y afligidos son los bienaventurados que heredarán el Reino de los Cielos (Mt 5,3; Lc 6,20). Ellos serán los primeros destinatarios de las promesas mesiánicas (Lc 7,22).

En el posexilio, el término será aún más matizado, porque la situación de los que regresaron no era fácil. La pobreza crecía y la necesidad de sobrevivir provocaba, en muchas ocasiones, grandes injusticias sociales. No alcanzaba el "salario" para subsistir y la "inseguridad" reinaba $(Z c 8,10)$. En este contexto, aparece el III Isaías, quien se dirige a los pobres de Sión y les da la buena nueva: ellos recibirán la auténtica liberación que viene de Dios (Is 61,1ss.), ya que sus escasos recursos económicos no les permitían una plena participación en la comunidad reunida.

Estos grupos solían ser marginados de las estructuras e instituciones vigentes ${ }^{29}$. Por ello, el profeta llama a que el Templo sea casa de oración "para todos los pueblos" (Is 56,7), donde los eunucos puedan tener un "nombre eterno" (Is 56,5), mejor que

\footnotetext{
28 "Buscad al Señor, vosotros todos, humildes de la tierra que habéis cumplido sus preceptos; buscad la justicia, buscad la humildad” (So 2,3).

${ }^{29}$ Kipper, “A mensagem social dos profetas pós-exílicos”, 77-104.
} 
el de las hijas y los hijos de Israel. Era un verdadero mensaje de reconciliación y universalismo.

Para comprender el talante de esta espiritualidad, vale la pena evocar las palabras del salmista:

...pues mi vida se consume en aflicción, y en suspiros mis años; sucumbe mi vigor a la miseria, mis huesos se corroen. De todos mis opresores me he hecho el oprobio; asco soy de mis vecinos, espanto de mis familiares. Los que me ven en la calle huyen lejos de mí; dejado estoy de la memoria como un muerto, como un objeto de desecho. Escucho las calumnias de la turba, terror por todos lados, mientras se aúnan contra mí en conjura, tratando de quitarme la vida. Mas yo confío en ti, Yahveh, me digo: ¡Tú eres mi Dios! (Sal 30,10-14)

La confianza es esa experiencia radical, no obstante la aflicción. Desde ella, los victimarios podrán quitar propiedades o trabajo, pero nunca la dignidad. Por eso, el pobre se relaciona de forma personal con Dios clamando, gritando confio en ti. No porque recibirá algo material a cambio de sus sufrimientos, sino porque ha encontrado en su relación personal con Dios lo que lo sostiene y le permite seguir viviendo, sin dejarse ahogar por el victimario y el poderoso.

En el siglo I d. C., los pobres de espíritu (anawin) e hijos de la tierra (am ha-arez) se caracterizaban por ciertos rasgos sociales y religiosos. Había grupos de la época que los despreciaban y consideraban gente sin honor. Podemos hacer referencia a tres rasgos fundamentales que influenciarán el modo de vivir de Jesús ${ }^{30}$ :

1. Aunque la pertenencia a este grupo social no estaba determinada por el estatus socioeconómico del individuo, sus miembros eran campesinos mayoritariamente, que vivían en pequeñas aldeas y trabajaban en el campo, a diferencia de quienes habitaban en grandes ciudades o eran terratenientes. Sin embargo, testimonios de la época dejan saber que también algunas autoridades o personas de grupos sociales medios y altos participaban de esta visión de Dios y del mundo, porque no estaban de acuerdo con el rígido judaísmo fariseo ni con el sistema injusto de tributos. El mismo Jesús tuvo fuertes altercados y diferencias con fariseos, levitas y saduceos.

2. La no observancia estricta y normativa de los ritos de pureza, más que responder a una actitud reaccionaria, se debía al modo como entendían y vivían la espiritualidad, muy distinta a la de los sacerdotes, levitas, fariseos, zelotas y otros grupos religiosos de la época. El estilo de vida de estos pobres abría interrogantes sobre lo verdaderamente esencial para ser fiel a Dios y bueno con el otro, como estaba normado en los dos mandamientos acerca del amor a Dios y al prójimo.

\footnotetext{
${ }^{30}$ Oppenheimer, The 'Am Ha-Aretz, 12.
} 
¿Cómo vivir, entonces? ¿Cumpliendo de forma estricta con los ritos y normas religiosas a pesar de que, en ciertas ocasiones, podían poner la propia vida y la del otro en peligro? ¿O apostar primero por el servicio y el cuidado del bien del otro? ¿Quién era más fiel al querer de Dios si se encontraba un día Sábado a un hombre asaltado y sangrando por el camino, el samaritano que era un impuro o el sacerdote que no podía impurificarse? ¿Se debía pagar un alto tributo, aun si esto ponía en riesgo la propia sobrevivencia económica de la familia que vivía de la pequeña producción de su tierra? ¿Qué era más eficaz? ¿La seguridad del rito y las normas de pureza, el alejamiento del pecador, o la apuesta por una vida movida por la compasión y la solidaridad fraternas? Todas estas cuestiones son expuestas por Jesús por medio de sus parábolas y gestos.

3. No limitar el conocimiento de Dios al estudio de la Torah y procurar vivir cada día con el mismo espíritu compasivo con el que Dios actuaba, produjo que algunos los calificaran como ignorantes de la Torah y, por tanto, los desestimaran abiertamente. Ellos no aprendieron a confiar sobre la base del conocimiento de una doctrina, ni sobre el hecho de contar con ciertas seguridades en sus vidas, sino apostando por un Dios que no los abandonaría en medio de las carencias de los bienes materiales y las experiencias de aflicción. Encontraban a Dios en las calles de sus vidas, no en los muros del Templo; tanto, que podían exclamar: "Yo me acuesto y me duermo, me despierto, pues Yahveh me sostiene. No temo a esas gentes que a millares se apostan en torno contra mî" (Sal 3,5-6).

\section{Discernir a Dios como pobre de Yahveh}

En la Palestina del siglo I, los pobres o anawin habían sufrido la dura y difícil experiencia de no tener nada: ni tierras ni posesiones - am ha-aretz-, pero aprendieron a descubrir ese rostro misericordioso de Dios. Jesús vive condiciones equivalentes en su propia realidad y las discierne como lo haría Yahveh, y no como un levita, fariseo o sacerdote. Hace suyo lo que Isaías proclama: "Los humildes y los pobres buscan agua, pero no hay nada. La lengua se les secó de sed. Yo, Yahveh, les responderé. Yo, Dios de Israel, no los desampararé" (Is 41,17). Jesús se entiende como representante y mensajero de este Dios, asumiendo las consecuencias que esto le traerá de parte de los que controlan el poder, tanto el religioso como el político.

Podemos recordar las palabras del Salmo 149: “...porque Yahveh se complace en su pueblo, adorna de salvación a los humildes (pobres/anawin)” (Sal 149,4) y condena a los "soberbios y poderosos" (1S 2,6-9). Todas estas palabras habían resonado en el corazón de María (Lc 1,46-55) y, desde allí fueron transmitidas al de Jesús ${ }^{31}$, quien

\footnotetext{
${ }^{31}$ Es precisamente al interior de su núcleo familiar, así como en el contexto religioso de Nazaret, donde Jesús aprende, oralmente, la tradición viva en el marco de una profunda espiritualidad, junto a su pueblo;
} 
las asumió y cargó para sí. María había sido el modelo de esta espiritualidad para él y así será luego recordada cuando el evangelista le atribuya las preciosas palabras del Magnificat ${ }^{32}$, porque en ellas se escucha la voz de quien ha sido el modelo perfecto de anawin para Jesús.

Como consecuencia de esta espiritualidad, podemos destacar dos actitudes que fueron fundamentales en su experiencia socio-religiosa: la no violencia como única forma de reaccionar frente al mal padecido (Is 53,7), y la solidaridad fraterna como medio de transformación de las relaciones sociales. Estas actitudes lo diferenciaban de los opresores ricos y poderosos de su época.

Jesús vivió con la libertad de un "pobre de espíritu", es decir, en una radical "disposición" personal de apertura ante la novedad de Dios, con una "actitud" bondadosa para con todo aquel a quien hacía próximo a él. Al vivir así pudó restituir la esperanza ante las duras "condiciones" de vida que padecían estos olvidados de la tierra, así como todos los afligidos y sufrientes de su mundo.

De ese modo lo narran los evangelistas, al señalar tantos gestos que Jesús tiene con diferentes personas cuando camina por los pueblos de Galilea. Él suscita la esperanza que, como pobre de Yahveh, no trae por la vía de un mesianismo poderoso. No realiza signos portentosos para demostrar que Dios está con él ${ }^{33}$, sino que va recreando lazos humanos basados en la solidaridad fraterna, como lo hacían los pobres, los enfermos y todos los afligidos de su tiempo para poder sobrellevar las cargas cotidianas.

Sin embargo, la pretensión última que lo llevó a vivir así no estaba motivada por el deseo de practicar determinada forma de vida espiritual, sino que fue naciendo de su deseo de querer ser tan perfecto en bondad como Dios, de su relación filial con Dios padre y creador (Mc 5,48); ese Dios que era capaz de recrear las historias de vida heridas por la religión y las costumbres sociales establecidas.

La experiencia de la bondad divina fue perfilando su humanidad hacia los más pobres y excluidos (Lc 6,36). De hecho, en el acontecimiento de su bautismo se reveló esa maravillosa experiencia de sentirse amado por el Padre (Mc 1,11) y de participar solidariamente en la fila de los excluidos y rechazados. Dios se le manifestaba como "rico en misericordia y lento a la cólera". Esta había sido la experiencia en su oración (Sal 86,15; 103,8), donde resonaba el recuerdo del Dios de la alianza (Ex 34,6; Dt 4,31).

estos le diferenciarán en el modo de aprendizaje y estudio de los doctores y maestros de la Ley de su época. Ver a Vasco, Le Psauties de Jésus, I, 72.

${ }^{32} \mathrm{Al}$ referirse al "Magnificat", Gelin explica que nos encontramos con un himno de los pobres, los no favorecidos por el mundo, que expresa tres actitudes que se confrontan directamente con Dios: "el orgullo (vv. 50-51), el poder (v. 52), y los ricos (v. 53)" (Gelin, The Poor of Yahweh, 96-97).

${ }^{33}$ Hooker, "Who Can this Be? The Christology of Mark’s Gospel", 94-98. 
Podemos, entonces, comprender por qué Jesús nunca se refirió a la teología de Sión, ya que simbolizaba el estado de gloria de Israel traído por David (2S 5,7), los anhelos de conquista, de posesión (1Cro 11,5), y la centralidad del culto como lugar donde Yahveh mostraba su poder ${ }^{34}$. Este símbolo alentaba las expectativas por restaurar el Templo y alimentaba el imaginario del poder político de Israel.

Incluso, en la época del exilio, se llegó a expresar en oraciones que pedían a Yahveh acciones de venganza en contra de todos los que habían oprimido al pueblo (Sal 137,1). Vivir así llevaba a abrigar la destrucción de los enemigos (So 3,19) y creer en un Dios guerrero, violento (Sal 46,7-12), antes que en la oferta libre de una relación personal en fe, por la sanación de los corazones afligidos. En el fondo de esta teología sinaítica latía una fuerte imagen del Dios todopoderoso (Sal 68,20.28-29.34-35), de la que se desprendía la creencia en que él podía intervenir en la historia en favor de su pueblo y en contra de sus adversarios.

Sería erróneo e incluso terrible pensar que, para Jesús, la imagen del Dios guerrero en los salmos hubiese significado la posibilidad de que Dios matara a sus opositores o desleales, o deseara hacerlo ${ }^{35}$. Antes bien, Dios es liberador. Es el quien ha sacado a su pueblo de la opresión egipcia y se le ha revelado en el monte Sinaí para llevarlo a Sión, donde se le ha de rendir culto ${ }^{36}$ como rey de todas las naciones. Aquel que ha sido el único guerrero, celoso cuidador de su pueblo, ahora será reconocido también como su único rey.

Lo que Jesús discierne y aprende de esta tradición sinaítica se decanta en una teología política, un modo de entender la relación entre Dios y el mundo que distinguirá dos caminos, dos modos de ser: el del Señor, Yahveh, único guerrero y rey, que evita que Israel tenga que pelear y matar y el de los señores de este mundo, que se arman y pelean ellos mismos, asumiendo la vía violenta, trayendo muerte y explotación.

Jesús asume la vía de la no violencia, que es la de Yahveh, y no la de los señores de este mundo; pero no traiciona la imagen del Dios guerrero, sino la entiende desde su sentido más real, la relee e interpreta a la luz de su experiencia como pobre de

\footnotetext{
${ }^{34}$ El término connota tanto la ideología davídica como el sentido glorioso de la realeza divina, simbolizando al gran Israel y su centralidad en el culto y el dominio de la tierra. Aunque la tradición davídica y la de Sión son distintas, o tienen orígenes diferentes, también encuentran puntos comunes en torno al Templo, el culto y el poder político como consecuencia del Reinado de Yahveh, por lo que se implican mutuamente. De ahí se entiende que Jesús no haya optado por ellas. Ver a Ollenburger, Zion: the City of the Great King. A Theological Symbol of the Jerusalem Cult, 59-60.

${ }^{35}$ Klingbeil, Yahweh Fighting from Heaven. God as Warrior and as God of Heaven in the Hebrew Psalter and Ancient Near Eastern Iconography, 134-135; 152-155.

${ }^{36}$ Ollenburger, Zion: The city of the Great King, 15-22. También recomendamos el interesante artículo de Jörg, "Lode und Zion”, 183-198.
} 
Yahveh. En otras palabras, lo entiende desde su celo por evitar que Israel se convierta en otra nación poderosa sobre esta tierra, desde su cuidado atento para con la viuda, el pobre, el marginado, desde aquel que nunca arma a nadie ni lo prepara para la guerra, sino al contrario, lo desarma.

La superioridad de Israel nunca será medida por su capacidad para ejercer la fuerza y someter a los otros con su poder militar, sino por la soberanía absoluta que se le reconoce a Yahveh en todo lo que hace. Este discernimiento será crucial para Jesús y lo expondrá con su visión del Reino-reinado.

Él no optará por construir otro reino político, como habían intentado los macabeos, ni como hizo David al querer asemejarse a los imperios que lo circundaban. Tampoco asumirá la vía de los zelotas, que terminó con una horrible mortandad que llevó a los romanos a tomar a Jerusalén y a destruir el segundo Templo. Él había entendido que reconocer a Yahveh como único guerrero y rey implicaba el camino del Hijo del Hombre, cuya sabiduría habría de llevar a la plenitud la promesa mediante el servicio profético al pobre y al enfermo ${ }^{37}$.

Así podemos comprender por qué Jesús nunca optó por el camino de la liberación sociopolítica o la recuperación de la tierra ocupada por el Imperio Romano, ni por la vía de la reforma del culto o la actualización de todas las normas prescritas por el Deuteronomio ${ }^{38}$. Su atención estaba puesta en el servicio fraterno a los hijos de la tierra, los am ha-aretz, los desposeídos y excluidos de su sociedad, sin niguna pretensión restauracionista ${ }^{39}$.

Más bien, Jesús describe a Yahveh como el Creador, el dueño de la tierra y el dador de la vida. Su lenguaje toma como ejemplos imágenes provenientes de los frutos de la tierra y del sentido para el cual estos fueron entregados al hombre. Desde allí podía convocar a una nueva alianza que ya no sería un contrato, sino un banquete, y que no se basaría solo en la elección de las hijas y los hijos de Israel sobre las garantías de tener a Abraham por padre (Mt 3,9).

La nueva alianza asumiría la causa de los pobres y aprendería de ellos a confiar en ese Dios creador, tal y como Abraham había apostado por Dios también. Jesús

\footnotetext{
${ }^{37}$ Lind, The Theology of Warfare in Ancient Israel, 173-174.

${ }^{38}$ De los tres aspectos fundamentales de la teología deuteronomista -a saber, la elección, el culto y los sacrificios-, el aspecto central que conforma el sentido del texto y sobre el cual se consolida y practica la elección del pueblo para medir su fidelidad será la centralidad del culto (Lohfink, Studien zum Deuteronomium und zur deuteronomistischen Literatur, 140ss.).

${ }^{39}$ En este sentido, las acciones de Jesús eran escatológicas, en continuidad con el judaísmo del siglo I, pero nunca restauracionistas. No obstante, Sanders y otros recientes investigadores del Jesús histórico siguen sosteniendo el carácter restauracionista de Jesús (Sanders, La figura histórica de Jesús, 205-206).
} 
sabía que si Israel se convertía en un imperio más, podía oprimir a otros pueblos, como ellos habían sido oprimidos. De víctima pasaría a ser victimario. Ese no era el querer de Dios. Yahveh había liberado a Israel para ser testimonio de que ningún sujeto merecía la opresión, el sufrimiento ni la humillación.

De esta experiencia de Jesús se infiere una teología creacional subyacente. Veamos algunos de sus rasgos, así como su diferencia respecto de otras teologías e imágenes de Dios que existían en el contexto del siglo I y que pudieron haber sido seguidas por Jesús.

\section{Discernimiento contextual de la teología creacional}

Un rasgo del siglo I es la existencia de un contraste evidente entre el modo cultual y legalista, como se entendía el encuentro con Dios, y el anuncio vivo y cotidiano -hecho por Jesús- de un Dios cercano, compasivo, abierto a todos, que no exige pasar por los pilares de la religión establecida (a saber, el Templo, el sacrificio, el sacerdocio). Por ejemplo, podemos decir que, en la praxis de Jesús, no aparece en ningun momento gesto o palabra alguna que vaya por el camino cultual y legalista.

Todo lo contrario, en él resuenan las palabras de los salmos con los que oraban los pobres de Yahveh: "Ni sacrificio ni oblación querías, pero el oído me has abierto; no pedías holocaustos ni víctimas, dije entonces: Heme aqui, que vengo. Se me ha prescrito en el rollo del libro hacer tu voluntad" (Sal 40,6-8).

"Heme aquî": esa disposición con la que Abraham, y también Isaías, habían puesto sus vidas al servicio de la escucha de las palabras del Señor (Gn 22,11; Is 6,8) para poder hacer su voluntad. Vivir así implicaba una fuerte necesidad de creer que Dios era realmente así; y dado que Dios era así, él, Jesús, su mensajero, se sentía con la autoridad de anunciarlo a los demás.

Jesús nunca pretendió formar un nuevo acuerdo ${ }^{40} \mathrm{o}$ alianza entre el pueblo y Dios. Su novedad provenía de haber aprendido a tratar a Dios de forma personal; de disponerse personalmente ante él y entregarse en servicio a los demás: "Heme aquî". Su praxis demuestra que él estaba convencido de que Dios era así como él lo anunciaba, de tal modo que la Ley y el culto solo eran mediaciones absolutas para acercársele, porque el Reinado de Dios “ya” estaba aconteciendo (Mt 12,28).

El Señor ya había abierto los "oídos" (Is 40,5), hacía de sus palabras "carne y corazón” en cada quien (Jer 31,33), insuflaba aliento para escucharlo porque había

${ }^{40}$ Lohfink, The Christian Meaning of the Old Testament, 90. 
dado su palabra como "alimento" eterno (Ez 3,2) $)^{41}$. La promesa se estaba realizando como un acontecimiento en proceso a través de sus palabras y gestos.

\section{Optar entre teologías y modelos de fe}

El proceso de discernimiento de Jesús no se da por un seguimiento literal, acrítico, de las distintas imágenes de Dios que existían en el siglo I. Su espiritualidad lo lleva a discernir las escrituras de modo particular y a optar entre las distintas teologías y modelos que existían y convivían en el judaísmo ${ }^{42}$. No podemos abolir la variedad de tradiciones y formas de vivir la fe que existían en el judaísmo del siglo I; pero sí podemos decir que, para Jesús, no todas eran fieles al Dios del Reino, al Dios en quien él creía y a quien le oraba.

Una de esas teologías y formas de vivir la fe con las que Jesús no simpatiza es la teología sacerdotal expresada en innumerables normas de pureza ${ }^{43}$, así como no estaba de acuerdo con las altas cargas impositivas que tenían que pagar los pobres a Roma fruto de las políticas colaboracionistas de Antipas ${ }^{44}$. Tampoco favoreció la práctica de los ritos sacrificiales ni el rezo de devociones ${ }^{45}$ que muchos consideraban como únicas mediaciones eficientes, en sí mismas, para encontrar a Dios y ser perdonados ${ }^{46}$.

\footnotetext{
${ }^{41}$ Barbiero, Il regno di JHWH e del suo Messia, 360-363.

${ }^{42}$ Scott, Jewish Backgrounds of the New Testament, 266-269.

${ }^{43}$ Según la tradición judía del primer siglo, bien testimoniada, el problema no consiste en que el sacerdote o el levita se puedan purificar, sino que no se deben impurificar en ningún caso. Es interesante repasar los comentarios bíblicos de Luis Alonso Schökel sobre la parábola del buen samaritano, así como los de Francois Bovon, Juan Mateos, Fernando Camacho, John Dominic Crossan y del teólogo judío Brad Young sobre el tema. Además de los textos de estos exegetas están los de la Torah, especialmente, y con mucha claridad, los libros de Vaikrá, Levítico 11-16; Bamidbar, Números 3-18; Lejezkel, Ezequiel 40-48. También hay referencias extrabíblicas en los escritos de Flavio Josefo. Posteriormente, la tradición oral que se mantenía en el siglo I fue recogida y puesta por escrito en la Mishná, a fines del siglo II d. C., y
} se endureció lo que la misma Torah sostenía.

${ }^{44}$ Existía el pago de tributos, tasas impositivas y diezmos. No solo había que pagar un tributo a Roma (tributum soli y tributm capitis), sino que también Antipas contaba con un sistema de cobro sobre la producción de la tierra. Además, existía el pago de las ofrendas al Templo para poder realizar los sacrificios. En fin, este sistema se caracterizaba por una gran inequidad. Los mayores beneficiados eran tanto los romanos como las élites políticas y religiosas de Israel, especialmente en Jerusalén, a costa de altas cargas económicas puestas sobre las espaldas de los campesinos, quienes muchas veces perdían sus propiedades y quedaban en la calle, al no poder cumplir con esas injustas obligaciones. No les quedaba más que ir a las plazas públicas a buscar trabajo como jornaleros, para sobrevivir el día a día (Mt 20,3).

${ }^{45}$ En ese contexto y en contra de lo establecido, Jesús decía: “....aprended lo que significa: 'Misericordia quiero y no sacrificios, porque no he venido a llamar a justos, sino a pecadores"' (Mt 9,13). La misericordia, y no las prácticas sacrificiales o devotas, es la relación por excelencia que nos asemeja a Dios. La expresión latina miserere se traduce al español como compasión y habla del modo como Dios se revela: "compasivo y clemente, lento para la ira y abundante en misericordia y verdad" (Ex 34,6-8). Es un Dios que "no pide sacrificios" (Sal 50).

${ }^{46}$ Basta recordar Mc 2,23-27. 
Su imagen de Dios también se distanciaba de la del Dios fuerte del Sinaí y del Éxodo de la teología deuteronomista, cuya orientación acentuaba la posesión de la tierra y la diferenciación de los espacios en ella (como sagrados o no) sobre la propia vida de quienes la poblarían. Esta teología relativizaba la relación de confianza que debían tener los creyentes con su Creador ${ }^{47}$ y ponía su atención en la mediación cultual como acceso al único Dios. Entendía que, debido a la revelación personal que Yahveh hace de su nombre, el pueblo pasaba a pertenecerle de forma exclusiva al modo de una unión familiar.

El culto será signo de separación respecto de los otros pueblos, lugar de reunión de los miembros de Israel y expresión del encuentro con Dios. Porque no cabía la separación entre el hecho de tener una relación personal con Dios y la participación en su culto según esta teología deuteronomista ${ }^{48}$. Sin embargo, esto es algo que Jesús separa de forma definitiva, todo lo cual irá forjando una identidad religioso-política muy sólida como pueblo "elegido" y, por tanto, "separado", algo que el mismo Jesús tendrá que discernir y ante lo cual optar, si vivir así o distanciarse de la imagen de Dios subyacente a esta teología.

Por medio de los mandamientos - la alianza contractual que establece Yahveh con su pueblo- se había constituido al culto como el lugar de reconocimiento del verdadero y único Dios: se debía adorar solo a Yahveh y rechazar toda otra forma de deidad existente entre los pueblos vecinos (Dt 5,9; 6,12-15). Jesús actualiza y trasciende ${ }^{49}$ estos dos principios -el de separación sagrada y el de la absolutez de la mediación cultual- al proclamar, con gran énfasis, un único mandamiento, el del amor, colocando en un mismo plano de exigencia horizontal, el amor a Dios y al prójimo (Mt 22,37-40).

No puedo separarme de mi hermano para estar con Dios, ni lo encontraré en un lugar apartado y sagrado, porque a Dios lo encuentro en la vida de mi hermano,

\footnotetext{
${ }^{47}$ Son dos teologías distintas. "Mientras una identifica a la felicidad con la prosperidad lograda en la tierra prometida y la descendencia; la otra trata, simplemente, de alcanzar una vida plena. El primer símbolo traiciona a la mentalidad de la alianza patriarcal y deuteronomista; el segundo, en cambio, muestra la visión de la tradición sapiencial" (Nguyen, "Figlio mio: se il tuo cuore é saggio", 245).

${ }^{48}$ Gese, Vom Sinai zum Zion, 75.

${ }^{49}$ Jesús no viene a abolir la Ley y los profetas sino a llevarlos a su plenitud (Mt 5,17). Tal noción se inserta en el marco de la tradición de su pueblo, donde la historia no es entendida como una experiencia cíclica o como una serie de eventos que se repiten en diversos periodos. La misma alianza, en este sentido, se fue renovando en diversos momentos de la historia del pueblo. La plenitud del Reino que acontece de forma definitiva y por siempre no permite otra actualización, pues revela lo que los profetas anhelaban y el pueblo había esperado tanto, como manda a preguntar Juan el Bautista a Jesús. Ver a Lohfink, The Christian Meaning of the Old Testament, 133-137, esp., 136.
} 
en la cotidianidad compartida ${ }^{50}$. Él es el Dios de la vida (Mc 12,26-27) y su único deseo es que el hombre viva (Lc 20,37-38) ${ }^{51}$. De ahí que Jesús opte por otra teología más cercana a todos los que vivían la espiritualidad de los pobres de Yahveh e hijos de la tierra: la teología creacional. Esta acentuará la relación en la fe, como confianza puesta en la bondad del Creador que apostó por el hombre al crearlo, al mostrarse como un Dios de la vida.

Ciertamente Jesús reconoce que Moisés dio paso al conocimiento del rostro del Dios único y verdadero (Ml 3,22). Sin embargo, él no buscó a Dios donde Moisés lo halló, sino allí donde la gente de su pueblo lo estaba rastreando, en la predicación del profeta Juan, en aquel llamado profético, y no sacerdotal, que hace el Bautista. Lo encuentra participando en la misma fila que sus hermanos hacían para ser bautizados.

En este sentido, movido por el mismo Espíritu que ellos, pide por una sincera conversión del corazón ante la gravedad de lo que se vivía en la Palestina del primer siglo. Seguía así el clamor de Juan (Lc 13,32; Mt 3,7). En esa experiencia halla a un Dios que lo acoge como Padre y lo asume desde abajo, como su hijo amado ${ }^{52}$; un Dios que apuesta por la vida de los sujetos y los bienes de la tierra: el Dios creador.

Como buen galileo, en Jesús resonaban las tradiciones proféticas del norte, inspiradas en Elías, Eliseo o Jonás, más que las de reyes y sacerdotes propias de Jerusalén y Judea. Él nunca se refiere a la teología de Sión ${ }^{53}$ y la ciudad santa en la que se unía el ideal del poderío político -simbolizado por David- con el centralismo del culto en

\footnotetext{
${ }^{50}$ Se trata de una de las grandes diferencias del modo como Jesús entendía la presencia de Dios respecto de su tiempo y tradición, porque mientras tanto se seguía insistiendo en que había lugares, tiempos, cosas y personas sagradas, o más cercanas a Dios y distantes de los hombres, así que el paradigma de encuentro con Dios era el de Moisés, que se acercaba con temor a Dios subiendo hasta él, en el Sinaí. Ver a Gomá Civit, "Santificado sea tu nombre", 300-301.

${ }^{51}$ Como decíamos previamente, ya el simple hecho de odiar al hermano es análogo a asesinarlo (1Jn $3,15)$. No existe, pues, un amor a Dios que no pase, necesariamente, por el amor fraterno.

${ }^{52}$ Como lo expresa hermosamente Pagola: “Todo es diferente de lo vivido trece siglos antes por Moisés en el monte Horeb, cuando se acerca tembloroso a la zarza ardiendo, descalzo para no manchar la tierra sagrada. Dios no dice a Jesús: 'Yo soy el que soy', sino 'tú eres mi hijo'. No se muestra como misterio inefable, sino como un Padre cercano que dialoga con Jesús para descubrirle su misterio de Hijo: 'Tú eres mío, eres mi hijo. Tu ser entero está brotando de mí. Yo soy tu Padre'. El relato subraya el carácter entrañable y gozoso de esta revelación. Así la escucha Jesús en su interior: 'Eres mi hijo querido, en ti me complazco"” (Pagola, Jesús. Aproximación histórica, 305).

${ }^{53}$ Es interesante ver el paso que se va dando en el libro de Isaías de una noción etnocéntrica de Israel hacia un universalismo que la entiende desde su misión de ser luz para todas las naciones, reconociendo que debe integrar a los pueblos en el plan salvífico de Yahveh, un paso que algunos autores atribuyen al proceso que el mismo Jesús tuvo que hacer en su propia conversión a Dios. Ver a Bergesm, "Die Zionstheologie des Buches Jesaja", 167-198.
} 
torno del sacerdocio y del Templo ${ }^{54}$. Esta es otra de las teologías de las que Jesús se distancia, y denuncia con preocupación que se ha perdido la fe según el modelo de Abraham porque se ha exacerbado la normatividad mosaica.

Por medio de Moisés se había revelado un Dios que le entregaba la tierra al pueblo elegido (Dt 14,2), con la condición de que observara los mandamientos y preservara la alianza mediante el culto al único Señor (Dt 11,1). Este sentido contractual de la alianza, que pasaba por la posesión de una tierra, había sido renovado por Josías. Se basaba en "cumplir los mandamientos" y "preceptos" con todo el corazón y toda el alma (2R 23,1-13): aquellos que Moisés, como mediador de la Ley, entregó luego a los sacerdotes y ancianos, como nuevos mediadores del pueblo, para que garantizaran su cumplimiento (Dt 31,9).

A diferencia de esta teología mosaica, estaba el modelo de la fe de Abraham que recordaba el trato personal con Dios como fuente de toda religación, de toda conversión personal y de todo proceso de recreación histórica. Había dos expresiones de Abraham que quizás tocaron el corazón de Jesús, porque describían esa relación de recíproca confianza, de cuidado mutuo entre Dios y sus hijos: primero, la disposición personal de quien dice "heme aquî" (Gn 22,1.11); segundo, el creer que Dios cuida y vela por cada uno de sus hijos en sus luchas cotidianas por el pan diario, porque "Yahveh provee" (Gn 22,14).

Una relación así con Dios entendía al culto como una expresión relativa, secundaria, porque la vida humana y la confianza puestas en Dios eran lo primero, lo fundamental. En este sentido, podemos decir que porque Abraham confió, fue salvado y bendecido (Gn 22,16-17). De allí que Jesús recuerda que, en los inicios, el modelo era Abraham, y no Moisés (Mt 19,8). Lo que lo inspiraba, entonces, era esa praxis de inclusion, de reconciliación entre los judíos y de ellos con los otros pueblos, y no el dominio y la posesión de la tierra prometida ${ }^{55}$.

De este modo, Jesús se situaba frente a diversas teologías o visiones de Dios, y su relación con el mundo y la tierra ${ }^{56}$; y, en medio de todas ellas, opta por el modelo

\footnotetext{
${ }^{54}$ Roberts, "The Old Testament's Contribution to Messianic Expectations", 48.

${ }^{55} \mathrm{El}$ modelo abrahámico significaba, a su vez, la inclusión de todos aquellos que vivían más allá de las fronteras oficiales de Israel, como lo recuerda Freyne. Con ello, Jesús simbolizaba el sentido de la reunión de "todos" en la nueva familia (Freyne, A Jewish Galilean, 77).

${ }^{56}$ Estas dos teologías se fundamentan sobre los siguientes modelos bíblicos: el "modelo abrahámico", que simboliza la itinerancia del pueblo de Dios y el siervo obediente, sin tierra, que responde al llamado divino para ir a lugares desconocidos; y el "modelo mosaico", o deuteronómico, que imagina a la salvación como el regalo que Dios hace de una vida buena en una tierra estable y fértil. Ver a Miller, "The Gift of God. The Deuteronomic Theology of the Land”, 454.462.
} 
abrahámico, de cuyo estilo itinerante llegará a comprender que la fidelidad no está basada en el cumplimiento de la Ley ni en la práctica del culto, como tampoco en la posesión de una propiedad o en la pertenencia a una familia, sino en la confianza de quien no tiene nada y vive, de forma absoluta, de la compasión divina y la entrega fraterna.

El Dios bueno y creador había puesto los bienes de la tierra para el disfrute de "todos" sus hijos, al darles lo mejor de sí. Les entregó algo "bueno" (Gn 1,31). Tal creencia se basaba en que Dios era el dueño y señor de la tierra (Gn 15,18), y no los poderosos e imperios de este mundo (Ez 36,5). Israel tenía el derecho de cuidarla y beneficiarse colectivamente de ella. La creación era para el disfrute y el desarrollo de la vida de todo el pueblo ${ }^{57}$, antes que de unos pocos.

Si Jesús hubiese asumido la teología deuteronomista, la tierra no solo hubiera significado ese espacio de disfrute y reconciliación querido por Dios desde el inicio, sino -ante todo- el lugar de la identidad nacional y la diferenciación respecto de los otros pueblos. Si bien es cierto que la tierra seguía simbolizando el "cuidado" amoroso y el salvífico de Yahveh por su pueblo - pues Dios mismo era su donante (Dt 34,4)-, pasó luego a ser un imperativo que el pueblo tomara posesión de la tierra prometida destronando a los enemigos de Israel, como signo del "poder" y la "superioridad" de Dios, así como de la "elección" de este pueblo y no de otros (Dt 25,19)

De la posesión de la tierra se deriva la normatividad de la vida en ella, mediante los mandamientos o palabras queridos por Dios. De ahí que Jesús se distancie de esta forma de entender la presencia y el querer de Dios, y las relaciones entre los sujetos. Él asume el modelo de la fe itinerante y confiada de Abraham, inspirado en una teología creacional, antes que el otro modelo normado y estable de Moisés. Era ese modelo creacional el que más se acercaba a su propia espiritualidad.

\section{Consecuencias de esta apuesta en fe}

¿Qué consecuencias tiene en Jesús este modo de vivir la fe y entender a Dios desde la espiritualidad de los pobres de Yahveh? ¿De qué modo configura a su propia humanidad esta creencia en un Dios creador, que quiere humanizarnos y devolvernos los bienes de la tierra? ¿Cómo expresa en su propia praxis cotidiana lo que él mismo vivía ante Dios y con los demás?

Jesús va abriéndose a los otros para invitarlos a confiar (Jn 14,1) y cargarlos como hermanos. Así les fue devolviendo la esperanza de vivir (Mt 11,28; Is 53,11).

\footnotetext{
${ }^{57}$ Levine, "The Promised Land of Milk and Honey", 161-163.

${ }^{58}$ Miller, "The Gift of God", 455.
} 
Esta apertura a los otros le cambió la vida a él${ }^{59}$ y encontró una fe inmensa donde menos lo esperaba que le abrió el propio horizonte. La nueva imagen de Israel no se realizaría más en torno del Templo ni de sus prácticas, porque estaba convertido en una "cueva de bandidos", en un auténtico comercio sagrado (Jr 7,11; Mc 11,17). Él estaba convencido de que las autoridades políticas y religiosas habían optado por sostener la pax romana a costa del sufrimiento y las duras cargas de los pobres (Is 66,3-4).

Como pobre de Yahveh e hijo de la tierra, el símbolo del Israel fiel será la nueva "familia de las hijas e hijos de Dios" que escuchan "fraternalmente" la palabra y comparten "solidariamente" los bienes de la tierra. No será la restauración de las doce tribus de Israel y todo lo que ello simboliza. Esto llegó a asombrarle tanto a él como a quienes lo seguían, porque era algo completamente nuevo; tanto así que impactó a sus seguidores más cercanos, incluido Pedro.

Este recuerdo lo representaron los evangelistas a lo largo de varios encuentros que tuvo Jesús cuando fue a visitar algunos pueblos de Galilea y de otras regiones que no eran consideradas como parte del gran Israel. En esa familia abierta, no biológica, cabía la fe de un centurión (Mt 8,5ss.), la de una mujer sirofenicia (Mc 7,24-30), junto a la de tantos judíos piadosos que habían sido marginados y despreciados, y que vivían en pequeñas aldeas (Lc 16,19-31).

Jesús estaba convencido de que Dios no quería que nadie dejara de encontrar de nuevo la esperanza de vivir, porque Yahveh nunca abandonaba al desvalido ni al humilde. Así lo pudo haber discernido en el Salmo 35: "Yahveh, ¿quién como tú, para librar al débil del poderoso, y al pobre de su explotador?” (v. 10). También en el profeta Isaías: “...porque los montes se correrán y las colinas se moverán, mas mi amor no se apartará de tu lado y mi alianza de paz no se moverá, dice Yahveh, que tiene compasión de ti" (Is 54,10).

Solo desde la bondad de lo creado y la compasión divina era posible que se produjera un auténtico reencuentro entre el Creador y sus criaturas, porque eran "hijas e hijos de Abrahám" y podían reencontrarse nuevamente en una misma fe.

El discernimiento de Jesús iba teniendo lugar desde el Dios creador. Su intención no era saber quién era Dios, sino cómo era su modo de actuar y estar presente entre nosotros, recreando nuestras historias y sanando nuestras heridas. Esto implicaba responder a una serie de preguntas que seguramente Jesús se hizo. Por ejemplo, la de cómo había imaginado Dios que fuese este mundo, que plantea el problema de la tierra y de la creación. ¿Cómo entender la realeza divina distante de todo honor,

\footnotetext{
${ }^{59}$ Lo que algunos han llamado como la crisis de Galilea, que Freyne refiere como su visión del gran Israel y la fe más allá de las fronteras. Ver a Freyne, A Jewish Galilean, 60-91.
} 
estatus y poder socioeconómico, político y religioso? ¿De qué reino es Dios rey? De aquí surge la tensión entre el Reino de Dios y los reinos de este mundo. ¿Cómo representar el querer del Padre y comunicarlo a todos como buena noticia que estaba ya aconteciendo sin violencia y con la fuerza de la fraternidad? Lo que representa el conflicto de la autoridad y el poder.

De la respuesta a estas y muchas otras preguntas se desprende una visión de la sociedad y se hace visible el modo como Jesús entendía que Dios estuviera presente en ella; pero muy especialmente de allí sale un modo de entender la relación entre el poder y el servicio en pro de la puesta en práctica de una vida capaz de actualizar bumanamente el querer divino.

Jesús no será, pues, como Moisés, un intercesor ante Dios que mediaría su ley para llevarla a cumplimiento. Jesús será su representante, el profeta que actuará con la pretensión de hablar en nombre de él y anunciar que ya está actuando, de forma personal, mediante el acontecimiento de la llegada de su reinado. Sus palabras, gestos, oraciones, acciones, encarnaban ese gran acontecimiento recreacional.

Moisés también había conocido al Dios "compasivo y misericordioso, rico en amor y renuente a la cólera” (Ex 34,6), pero no fue esa la experiencia con la que midió su fidelidad a la alianza ni la altura de su relación con Dios, sino el cumplimiento de las normas, los mandamientos y las prácticas cultuales.

Como hemos visto, en Jesús, por el contrario, estaba aconteciendo algo completamente nuevo, que incluso brotando de su propia tradición, la trascendía desde su íntima unión como "hijo amado" que quiso vivir solidariamente con sus hermanos porque deseaba ser tan "bueno y compasivo" como era su Padre. Es así que, como "pobre de Yahveh" (anawin), entregado al rescate y la sanación de "los hijos de la tierra" (am ha-arez), no tuvo necesidad de abolir la Ley, pero sí de superarla, llevándola a su verdadera plenitud, aquella en la que lo humano podía alcanzar una calidad de vida divina, para vivir "aquí en la tierra como en el Cielo".

Esto lo hará desde su fe en el Dios del Reino. Tal será el criterio para su discernimiento y no la Ley, el culto o los profetas. Por ello, las tradiciones restauracionistas más duras que existían en su época no jugarán un papel importante en su vida. Él las rechazará, como se lo hizo saber a Pedro (Mc 8,29-33) ${ }^{60}$. Su experiencia

${ }^{60}$ Pedro esperaba a un Mesías que fuera un guerrero combativo y pusiera fin a la opresión romana; por ello le confiesa a Jesús: "Tú eres el Mesías" (Mc 8,29). Jesús lo manda a callar. ¿¿Por qué? Pedro entendía que la única forma de mesianismo posible era la revolucionaria y militante, que pudiera atraer a las masas para asaltar el poder. Así que ante la confesión de un mesianismo de este tipo, Jesús reacciona categóricamente diciéndole: “QQuítate de mi vista, Satanás! Porque tus pensamientos no son los de Dios" (Mc 8,33). La actitud de Pedro llevaba a matar. Recordemos que andaba armado (Jn 18,10). Jesús lo 
religiosa no será la misma de un zelota, que reaccionaría violentamente con ira y venganza contra su enemigo ${ }^{61}$, ni la de un fariseo satisfecho con el cumplimiento normativo de la Ley y el modo como oraba (Lc 18,9-14). Tampoco se parecerá a la del levita o del sacerdote en la observancia y práctica de las normas de pureza y culto (Lc 10,25-37).

La respuesta ante la crisis de su época y el clamor de los pobres debía nacer desde su relación personal con Dios, y no desde una ideología o un movimiento religioso determinado ${ }^{62}$, como hemos explicado previamente. Por ello, Jesús no predicó a Dios, sino su Reinado, es decir, su acción y presencia en medio de este mundo, al modo como él entendía que Dios debía estar actuando y recreando el estado de cosas de esta realidad. Solo así podía diferenciar el proyecto de Dios, que era el del Reino, de todos los otros proyectos de los diversos movimientos y grupos que había en su época ${ }^{63}$.

En este sentido, su vida se fue perfilando desde Dios, desde la radicalidad de sentirse amado por su Padre; y un hijo así podía entonces atraer a otros desde su humanidad, pues él era "uno como el Hijo del Hombre", "un pobre más", capaz de dar su vida, sin reservas, al estilo de un "siervo sufriente".

La vida de Jesús no solo replanteó las expectativas sociopolíticas y religiosas que existían en el siglo I, sino nos enfrenta a serias consecuencias para su seguimiento actual, en pro de la humanización de nuestras relaciones personales y las opciones personales e instucionales que hagamos en defensa de la vida, especialmente la de los más pobres y olvidados, la de los descartados y rechazados por el sistema.

\section{Bibliografía}

Barbiero, Gianni. Dio di misericordia e di grazia. Casale Monferrato: Piemme, 2002. . Il regno di JHWH e del suo Messia. Roma: Pontificia Università Gregoriana, 2008.

llama Satanás, que significa uno que es causa de división y deshumanización, siempre dispuesto a odiar o dar muerte a sus enemigos. El dios de Pedro no era el Dios a quien Jesús oraba.

${ }^{61}$ Este grupo se oponía fuertemente a la opresión a la que estaba sometido Israel bajo el Imperio Romano y pretendía una liberación militar. Pero también entendía que el Templo era el centro de la identidad nacional, política, que mediaba la consagración del pueblo a Dios por medio del culto. La liberación política tenía como finalidad la recuperación de la sacralidad del Templo y, con él, de todo el pueblo, pues habían sido profanados por los imperios. En este sentido, eran celosos de un sentir radical por la restauración político-religiosa del gran Israel. Tanto en el fin que perseguían como en los medios que usaban, Jesús se les oponía y nunca los favoreció. Ver a Marcus, "No More Zealots in the House of the Lord: A Note on the History of Interpretation of Zechariah 14:21", 22-30.

${ }^{62}$ Será, ante todo, una apuesta por la fe que pasaba por creer que se podía tratar a Dios de forma personal, sin hacer tratos e intercambios sagrados con él a través del culto, el sacrificio y los ritos de purificación.

${ }^{63}$ Lohfink y Pesch, Weltgestaltung und Gewaltlosigkeit, 32. 
Batto, Bernard F. y Kathryn L. Roberts (eds.). David and Zion. Biblical Studies in Honor of J.J. M. Roberts. Winona Lake (IN): Eisenbrauns, 2004.

Bauckham, Richard. The Jewish World around the New Testament. Grand Rapids (MI): Baker Academics, 2010.

Ben-Chorim, Schalom. Bruder Jesus. Der Nazarener in jüdischer Sicht. München: List, 1967.

Bergesm Ulrich. "Die Zionstheologie des Buches Jesaja”. Estudios biblicos 58 (2000): 167-198.

Büchler, Adolph. Der galiläische 'Am-ha 'Arets des zweiten Jahrhunderts. Hildesheim: Olms Verlag, 1968.

Bultmann, Rudolf. Teología del Nuevo Testamento. Salamanca: Sígueme, 1981.

Concilio Vaticano II. "Constitución dogmática Dei Verbum sobre la divina revelación”. Vatican, http://www.vatican.va/archive/hist_councils/ii_vatican_council/ documents/vat-ii_const_19651118_dei-verbum_sp.html (consultado el 7 de octubre de 2016).

. "Constitución pastoral Gaudium et spes sobre la Iglesia en el mundo actual". Vatican, http://www.vatican.va/archive/hist_councils/ii_vatican_council/ documents/vat-ii_const_19651207_gaudium-et-spes_sp.html (consultado el 7 de octubre de 2016).

Dunn, James. Christianity in the Making: Jesus Remembered, Vol. I. Grand Rapids (MI): Eerdmans, 2003. - Jesus and the Spirit. Grand Rapids (MI): Eerdmans, 1997.

Fitzmyer, Joseph A. The Semitic Background of the New Testament: Essays. Grand Rapids (MI): Eerdmans, 1997.

Flusser, David. Das Christentum, eine jüdische Religion. Munich: Kösel-Verlag, 1990. . Jesus in Selbstzeunissen. Hamburgo: Rowohlt Taschenbuch Verlag, 1968.

Freyne, Sean. A Jewish Galilean. London: T\&T Clark, 2004.

Gelin, Albert. The Poor of Yahweh. Collegeville (MN): Liturgical Press, 1964.

Gese, Hartmut. Vom Sinai zum Zion. München: Kaiser, 1974.

Gomá Civit, Isidro. “Santificado sea tu nombre”. RCat XXI/2 (1996): 300-301.

Helyer, Larry R. Exploring Jewish Literature of the Second Temple Period. Downers 
Grove (IL): InterVarsity Press, 2002.

Hooker, Morna. "Who Can this Be? The Christology of Mark's Gospel”. En Contours of Christology in the New Testament, editado por Richard Longenecker, 79-99. Grand Rapids (MI): Eerdmands, 2005.

Jeremias, Joachim. Abba. El mensaje central del Nuevo Testamento (6a. ed.). Salamanca: Sígueme, 2005.

Jörg, Jeremias. "Lode und Zion”. En Probleme biblischer theologie. Gerhard Von Rad zum 70, editado por Hans W. Wolff, 183-198. München: Kaiser, 1971.

Kimball, Charles A. "Jesus' Exposition of the Old Testament in Luke's Gospel”. Journal for the Study of the New Testament. Supplement Series 94. Sheffield: Sheffield Academic Press, 1994.

Kipper, Joao Balduino. "A mensagem social dos profetas pós-exílicos". Revista de Cultura bíblica 15 (1991): 77-104.

Klausner, Joseph. Jesús de Nazaret. Su vida, su época, sus enseñanzas. Barcelona: Paidós, 1989.

Klingbeil, Martin. Yahweh Fighting from Heaven. God as Warrior and as God of Heaven in the Hebrew Psalter and Ancient Near Eastern Iconography. Fribourg: University Press, 1999.

Levine, Étan. “The Promised Land of Milk and Honey”. Estudios biblicos 58 (2000): 145-166.

Lind, Millard C. The Theology of Warfare in Ancient Israel. Ontario: Herald, 1980.

Lohfink, Norbert. Das Jüdische am Christentum. Die verlorene Dimension. Freiburg: Herder, 1987.

. Option for the Poor. The Basic Principle of Liberation Theology in the Light of the Bible. Berkeley Lecture Series 1. Berkeley (CA): Bibal Press, 1987.

. Studien zum Deuteronomium und zur deuteronomistischen Literatur. Vol I. Stuttgart: Katholisches Bibelwerk, 1990.

. Studien zum Deuteronomium und zur deuteronomistischen Literatur. Vol. II Stuttgart: Katholisches Bibelwerk, 1991.

. The Christian Meaning of the Old Testament. Milwaukee (WI): The Bruce Publishing Co., 1968.

Lohfink, Norbert y Rudolf Pesch. Weltgestaltung und Gewaltlosigkeit. Ethische Aspekte des Alten und Neuen Testaments in ihrer Einheit und ihrem Gegensatz. Düsseldorf: 
Patmos, 1978.

Luciani, Rafael. "El Jesús histórico como norma hermenéutica para la teología y criterio para ser testigos en el seguimiento". ITER: revista de teología 37 (2005): 17-116.

Marcus, Joel. "No More Zealots in the House of the Lord: A Note on the History of Interpretation of Zechariah 14:21". Novum Testamentum 55 (2013): 22-30.

Meynet, Roland. Llamados a la libertad. Miami (FL): Convivium Press, 2007.

Miller, Patrick. "The Gift of God. The Deuteronomic Theology of the Land". Interpretation 23 (1969): 454.462.

Montefiore, Claud G. Some Elements in the Religious Teaching of Jesus. London: MacMillan and Co., 1910.

. "The Originality of Jesus". Hibbert Journal XXVIII (1929): 98-111.

. "The Significance of Jesus for His Own Age". Hibbert JournalX (1911-1912): 769-773.

. "What a Jew Thinks about Jesus". Hibbert Journal XXXIII (1934-1935): 511-520.

Moyise, Steve y Maarten J. J. Menken. Deuteronomy in the New Testament. London: T\&T Clark, 2007.

Nguyen, Dihn Ahn Nhue. "Figlio mio, se il tuo cuore è saggio": Studio esegetico-teologico del discorso paterno in Pro 23,15-28. Roma: Editrice Pontificia Università Gregoriana, 2006.

Ollenburger, Ben. Zion: The City of the Great King. A Theological Symbol of the Jerusalem Cult. Sheffield: Sheffield Academic Press, 1987.

Oppenheimer, Aharon. The 'Am Ha-Aretz. Leiden: Brill, 1977.

Pagola, José Antonio. Jesús. Aproximación histórica. Madrid: PPC, 2007.

Reed, Jonathan L. Archaeology and the Galilean Jesus. Harrisburg (PA): Trinity Press, 2002.

Rendtorff, Rolf. "Old Testament Theology, Tanakh Theology, or Biblical Theology? Reflections in an Ecumenical Context”. Biblica 73 (1992): 441-451.

Roberts, Jimmy Jack McBee. “The Old Testament's Contribution to Messianic Expectations". En The Messiah. Developments in Earliest Judaism and Christianity, editado por James H. Charlesworth, 31-51. Minneapolis (MN): Fortress Press, 1992. 
Sanders, E. P. La figura histórica de Jesús. Estella (Navarra): Verbo Divino, 2000.

Scott, Julius J. Jewish Backgrounds of the New Testament. Grand Rapids (MI): Baker Academics, 2007.

Stolz, Fritz. "Zion”. Theologisches Handwörterbuch zum Alten Testament II. München: Kaiser Verlag, 1971.

Uríbarri, Gabino. La singular humanidad de Jesucristo. Madrid: San Pablo, 2008.

Vasco, Jean-Luc. Le Psauties de Jésus. Les citations des Psaumes dans le Nouveau Testament. Paris: Du Cerf, 2012.

Vermes, Geza. Jesus and the World of Judaism. London: SCM, 1983.

_. Jesus the Jew. A Historian's Reading of the Gospels. London: SCM, 1973. . La religión de Jesús, el judio. Madrid: Anaya, 1996. . The Religion of Jesus the Jew. Minneapolis (MN): Augsburg Fortress, 1993.

Wellhausen, Julius. Einleitung in die drei ersten Evangelien. Berlin-New York: Walter de Gruyter \& Co., 1985.

Westermann, Claus. Das Alte Testament und Jesus Christus. Stuttgart: Herder, 1968.

Wierzbicka, Anna. What Did Jesus Mean. New York: Oxford University Press, 2001.

Winter, Paul. El proceso de Jesús. Barcelona: Muchnick, 1983. 